\title{
LOCAL PARTICIPATION LEVEL OF RURAL WOMEN IN HALABJA GOVERNORATE IN KURDISTAN REGION OF IRAQ
}

\author{
Abid A.H. Al-Doski ${ }^{1 *}$ and Chawan M.H. Saleh ${ }^{2}$ \\ 1. Coll. Agric., Dohuk Univ., Iraq \\ 2. Coll. Agric., Sulaimani Univ., Iraq
}

Received: 21/01/2017 ; Accepted: 16/05/2017

\begin{abstract}
The main objective of the study is to determine the Extension, social and political participation levels of rural women in Halabja Governorate, Iraqi Kurdistan Region and identify the relative importance of problems and obstacles of the local participation of rural women in the studied area. A Random sample of 200 rural women was selected and the data were collected by using a questionnaire consisted of four parts: The first part included a scale for extension participation measurement, the second part included social participation scale, and the third part included political participation scale while the fourth part included the problems and obstacles hindering rural women's participation. The main results of the study were: the majority of the studied rural women (52.5\%) had medium local participation level, (53.5\%) of them had medium extension participation level, (73.5\%) of them had medium social participation and (46\%) had medium political participation. The results also indicated that the (five) most important factors hindering rural women participation in the studied area are (Educational level and illiteracy among rural women in the studied areas, lack of confidence between rural women and politicians, political parties ignore the society objectives and interests, political life is centered in cities and highly populated and urban, the traditional attitudes of men toward women and the social role of each of them, the weak role of agricultural extension in supporting active participation of rural women in the region. Based on the results of the study, a number of recommendations were suggested, the most important was organizing awareness programs by agricultural extension and civil society institutions in order to increase local people's understanding of the significance of women's participation in sustainable rural development programs.
\end{abstract}

Key words: Participation, rural women, Halabja, Iraq.

\section{INTRODUCTION}

The rural development processes play a vital role in the rural life and community since they are planned processes designed to deploy and mobilize material and human resources within reach in the community and then draw the appropriate plans and implement them for the purpose of boosting the economic and social conditions of the people's communities (Harbi, 1997).

Women, without doubt, have played and are still playing a pivotal role in the genuine

\footnotetext{
* Corresponding author: Tel. : +201151172995

E-mail address: zsvp@yahoo.com
}

development process. Genuine development is the good utilization of the entire human and material resources. The obstacles, which obstruct their way are, as a matter of fact, the same as those facing the societies of the third world in general (Al-Leela and Al-Hafidh, 2011).

Depriving women of taking advantage of the human development service or preclude their participation in some services is, beyond any doubt, preclusion of half the society. Accordingly, development cannot be fulfilled without women involvement and that their active contribution cannot be accomplished, as long as they are facing problems and unfortunate 
conditions and actions must be taken to help them face and overcome them.

Talking about the participation of women in the development process and their abilities to develop and improve the condition of their families is definitely not limited to the urban women but also includes rural women by virtue of their participation in the social and economic development.

The roles of rural women vary in comparison with the roles of urban women since the former have multiple social and economic family activities; they are responsible for saving food consumption of their living units; they are the first school of social upbringing of the children; they are the strong and continuous element of supporting the head of the household, in family decision making, besides their active support in the production activity.

Women play crucial roles in the agricultural production in the developing countries, especially in countries with low income rate and where agriculture accounts for high ratio of the gross national production. Rural women represent the majority of the agricultural labor force in these countries because they produce the bulk of the locally consumed foods. This qualifies them to be one of the fundamental factors in achieving the economic development and family welfare in rural communities. Curbing all their agricultural potentialities constitutes a contributing factor in the slowness of development and absence of food security (World Bank, 2008).

Participating in the activities of rural communities is one of the subjects, which enjoys significant importance in the social sciences literature and the development policies of many developing countries, especially those related to women involvement, due to the particular importance of this subject in the development of local communities.

People's participation in rural community development programs leads to upgrading their skills, at all levels, throughout the whole stages of the programs. Thus, participation offers opportunities to each person to learn and acquire important skills and expertise.

The outcomes and recommendations, of many conferences and studies, highlight the need to pay attention to women and their participation in different aspects of life, in order to achieve a thorough development (Sherif, 1999).

Agricultural extension is considered one of the most important rural development organizations. Rather, it is one of its activities aiming at bringing about development, social and economic changes, and providing the ground for development. Though there is extension organization in the research area, this body is largely directed to men only, whereas the role of extension is to convey information to the rural family (rural man, rural woman and rural youth) as a complete production unit. Therefore, the extension organization, in spite of its role in providing guidance to rural women in the region, is not up to the expected level, which allows for raising their awareness and their skills (Ismail, 2013).

In view of the considerable importance of the participation of women in the affairs of the local community, and in the light of economic, social and political significances, being half of the society, the scarcity or absence of the studies, which dealt with the participation of women in general and the participation of rural women, especially, in Kurdistan Province and Iraq in general, this study is conducted as an attempt to answer the following queries:

What is the level of rural women participation in the extension, social and political aspects in the studied area? What are the problems and impediments affecting the degree of their participation?

\section{Objectives of the Study}

The Main Objective of the study is to determine the extension, social and political participation of rural women in Halabja Governorate, Iraq, and the specific objectives are:

1. To identify the local participation level of rural women in Halabja Governorate.

2. To identify the participation level of rural women in Halabja Governorate, in the extension, social and political areas.

3. To identify the relative importance of problems and obstacles of the local participation of rural women in Halabja Governorate. 


\section{MATERIALS AND METHODS}

\section{Population of the Study}

This study employs a geographical stratified sampling method. Halabja Central Governorate comprises of three sub-districts, namely Khormal, Seerwan and Bayara. Three villages, were randomly selected, one village from each sub-district. The selected villages were Xaellyhama (85 women), Zardahall (65 women) and Bamok (50 women). The total number of the rural women in the three studied villages was 395. A sample of 200 women were randomly selected. The size of the sample in each village is taken in proportion to the size of the village.

To achieve the objectives of this study, a questionnaire of four parts was designed: The first part includes a scale of (18) items to measure the extension participation of rural women in Halabja Governorate. The second part includes a scale of (18) items to measure the social participation of the rural women in the studied area. The third part includes a scale of (18) items to measure the political participation of the respondents. The fourth part consist of (16) problems and obstacles, hindering the rural women's participation in the Halabja Governorate.

The questionnaire was presented to the specialists and experts in the field of agricultural extension and educational psychology and social and political sciences, to give their comments on the type of questions and style of writing, clarity and accuracy of its measurement. Validity of the extension, social and political scales, were determined by using the Chronbach alpha with the values $(0.952,0.998,0.975)$, respectively. The data was analyzed and statistically treated by using arithmetical mean and percentages.

\section{RESULTS AND DISCUSSION}

\section{Local Participation of Rural Women in Halabja Governorate}

Local participation is considered as an important factor for the success and prosperity of rural development. A number of researchers have highlighted the role of people participating in rural development. Without community participation, there are, obviously, no accountability, no development and no program. Participation plays a crucial role in advancing the rural development as well as promoting rural and agricultural institutes (Aref and Ma'rof, 2009).

As shown in Table 1, rural women in Halabja Governorate are divided into three categories according to their local participation.

The results revealed that the largest proportion of the respondent (52.5\%) fell within the medium category level, followed by (29.5\%) of the respondent within the low category and dent (18\%) within the high category. The results clearly indicate that the overall local participation level of rural women in Halabja Governorate is in a descending order from moderate to low. Rural women's participation in the studied area can be improved, through different community awareness raising programs in addition to the active role of the agriculture extension and civil and nongovernmental institutions. Awareness raising programs may increase local people's understanding of the significance of women's participation in sustainable rural development programs.

\section{Participation Level of Rural Women in Halabja Governorate in the Extension, Social and Political Areas}

\section{Extension participation}

Women play a pivotal role in agricultural and rural economies in all developing countries. As agriculture is a relatively profitable income generating activity, women participating in it gain more control of the economic and social returns; making them self-reliant and enhances their empowerment status within the family, as well as, in the society, in general. As shown in Table 2, the rural women in Halabja Governorate are divided into three categories; according to their degree of Extension participation (High, Mid and Low).

The results revealed that the largest proportion of the respondent (53.5\%) fell within the medium category of extension participation, followed by $(14.5 \%)$ of the respondent within the high category and (33.5\%) within the low 
Al-Doski, et al.

Table 1. Distribution of Respondents, according to the degree of their local participation

\begin{tabular}{lcc}
\hline Category & Frequency & (\%) \\
\hline Up to 123 & 59 & 29,5 \\
$124-144$ & 105 & 52.5 \\
145 and more & 36 & 18 \\
\hline
\end{tabular}

Table 2. Distribution of respondents according to the degree of extension participation

\begin{tabular}{lcc}
\hline Category & Frequency & $\mathbf{( \% )}$ \\
\hline Up to 34 & 67 & 33.5 \\
$\mathbf{3 5 - 4 7}$ & 107 & 53.5 \\
$\mathbf{4 8}$ and more & 29 & 14.5 \\
& 200 & 100 \\
\hline
\end{tabular}

category of extension participation of rural women. This implies that the extension participation of the largest proportion of rural women in the studied area is in a descending order from moderate to low. This is largely due to the rareness and weak of extension activities in the studied area, therefore the concerned departments should work on improving the extension opportunities for the studied rural women.

\section{Social Participation}

The participation of rural women in household's decision-making, agriculture related activities, social occasions and governance is an important human rights issue. Women have the right to fully participate in all levels of community life.

As shown in Table 3, the rural women in the studied area are divided into three categories according to their social participation (High, Mid and Low).

The results revealed that the largest proportion of the respondent (73.5\%) fell within the medium category, followed by $(19.5 \%)$ of the respondent within the low category and (7\%) within the high category of social participation. This implies that the participation of the targeted rural women in the social activities lay mainly between low and medium. All studies found a lack of participation in social activities that may deprive rural women getting better livelihood opportunities. This could be due to the sociocultural considerations of the society, where there is strict adherence to religious, social and cultural values.

\section{Political Participation}

Political participation is one of the dimensions of effective community participation. Levels of political and civic participation and engagement are an effective gauge of social and political inclusion in any society, and engaged citizenry are a useful measure of the degree to which democracy is democratized. As shown in Table 4 the rural women in Halabja Governorate are divided into three categories according to their political participation.

Results in Table 4 reveal that the vast majority (46\%) of the respondents fell within the medium category, followed by $(29.5 \%)$ of the respondent within the low category and (24.5\%) within the high category of political participation. This implies that the participation of studied rural women in political and civic activities in their local communities lay mainly between low and medium.

Giving serious attention and support to the rural women and their various activities by government and non-governmental institutions 
Zagazig J. Agric. Res., Vol. 44 No. (4) 2017

Table 3. Distribution of respondents according to the degree of social participation

\begin{tabular}{lcc}
\hline Category & Frequency & $\mathbf{( \% )}$ \\
\hline Up to 41 & 39 & 19.5 \\
$\mathbf{4 2 - 5 2}$ & 147 & 73.5 \\
$\mathbf{5 3}$ and more & 14 & 7 \\
& 200 & 100 \\
\hline
\end{tabular}

Table 4. Distribution of Respondents according to the degree of political participation

\begin{tabular}{lcc}
\hline Category & Frequency & (\%) \\
\hline Up to 26 & 59 & 29.5 \\
27-33 & 92 & 46 \\
More than 34 & 49 & 24.5 \\
& 200 & 100 \\
\hline
\end{tabular}

on the local level, and enhancing the role of civil societies and the national mass-media in developing informative cultural and political awareness programs directed towards rural women, so that they can improve their social, political and economic status.

\section{The Degree of Importance of the Problems and Obstacles to the Participation of Rural Women in Halabja Governorate}

Rural women have played historical roles in agriculture development. They are mothers and home managers. They are decision makers at home and are involved in many other on-farm and off-farm activities. Although women play very important role in the subsistence oriented farming but they are facing many problems and constraints which hinder women from effectively participate in social and political activities. Table 5 shows respondents' opinions on the various factors that affect women's active participation in extensional, social and political activities in Halabja Governorate.

Results in Table 5 reveals that the most important factors that affects rural women's participation in the studied area is "Educational level and illiteracy among rural women in the targeted areas" (2.265). This is followed by the problem of "lack confidence between rural women and politicians" (2.205\%), Political parties away from the society objectives and interests (2.195), political life is centered in highly populated centers and urban (2.175), The traditional attitudes of men to women and the social role of each of them (2.165), The weak role of agricultural extension in supporting active participation of rural women in the region (2.016).

Results, further, reveal that women's education level and ratio of illiteracy among rural women, in the targeted area is the major challenge to women's socio-political aspirations. In the studied area, rural women constitute a larger percentage of the illiterate group and this translates directly into their inability to have their voices heard in the political sphere. Education is vital because it builds awareness and self-confidence required by women to voice informed opinions. Women who have acquired formal education are regarded with respect and enjoy increased opportunities for political participation. Knowledge is, therefore, an essential and critical ingredient required by women for meaningful participation in political activities. 
Table 5. Importance of the problems and obstacles to the local participation of rural women in Halabja Governorate

\begin{tabular}{|c|c|c|c|}
\hline No. & Paragraph & Limits of scores & Average \\
\hline 3 & $\begin{array}{l}\text { Educational level and illiteracy ratio among rural women in the } \\
\text { targeted area }\end{array}$ & $1-3$ & 2.265 \\
\hline 9 & Lack of confidence between Studied women and politicians & $1-3$ & 2.205 \\
\hline 15 & Political parties away from the society objectives and interests & $1-3$ & 2.195 \\
\hline 4 & political life centered in highly populated centers and urban & $1-3$ & 2.175 \\
\hline 1 & $\begin{array}{l}\text { The traditional attitudes of men toward women and the social role } \\
\text { of each of them }\end{array}$ & $1-3$ & 2.165 \\
\hline 16 & $\begin{array}{l}\text { The weak role of agricultural extension in supporting active } \\
\text { participation of rural women in the region }\end{array}$ & $1-3$ & 2.16 \\
\hline 10 & Society does not favor the work of women in political activities & $1-3$ & 2.15 \\
\hline 6 & $\begin{array}{l}\text { The weakness of government support for the activities of women in } \\
\text { the Studied area }\end{array}$ & $1-3$ & 2.14 \\
\hline 8 & $\begin{array}{l}\text { Not have time because of the nature of women's work at home or in } \\
\text { the field }\end{array}$ & $1-3$ & 2.14 \\
\hline & $\begin{array}{l}\text { The weak role of civil society organizations and their local } \\
\text { procedures }\end{array}$ & $1-3$ & 2.13 \\
\hline 5 & The weak financial support dedicated for women's organizations & $1-3$ & 2.12 \\
\hline & Objection of husband or father & $1-3$ & 2.11 \\
\hline 13 & Negative attitudes towards women's participation in public life & $1-3$ & 2.105 \\
\hline & Lack of political awareness among rural women in the targeted area & $1-3$ & 2.09 \\
\hline 2 & Values and prevailing social norms & $1-3$ & 2.08 \\
\hline 12 & $\begin{array}{l}\text { Women's economic dependence on men , which is a factor that } \\
\text { hinder their movement and participation }\end{array}$ & $1-3$ & 2.05 \\
\hline
\end{tabular}

\section{Conclusion}

The Results of this study indicated that the majority of the rural women in Halabja Governorate (52.5\%) had medium local participation level, 53.5\% of them had medium Extension participation level, $73.5 \%$ of them had medium social participation level, $46 \%$ of them had medium political participation level.

This means that the participation of rural women in the Halabja Governorate and in various areas was between medium and low. Agricultural extension services, NGOs and others sides should no longer continue considering women as, only, housewives and mothers; focusing mainly on male farmers. Improving participation of rural women in various areas of extension, social and politics is the best option for empowering rural women and increasing their status inside the family and the community.

The study results reveals that the 5 most important factors hindering rural women participation in the studied area, are (Education level and illiteracy among rural women in the targeted areas, lack confidence between rural women and politicians, Political parties away from the society objectives and interests, political life centered in cities and big population centers, The traditional position of 
men to women and, the social role of each of them, The weak role of agricultural extension in supporting active participation of rural women in the region)

Based on the results and observations made during the survey, it was clear that the participation of women in most areas is still less than the expectations. It is necessary to improve their participation in decision-making to enhance their empowerment as well as their status in the community.

\section{Recommendations}

Based on the results of this study, the following recommendations were made:

1. Agriculture extension in the studied area should encourage the formation and membership of cooperative organizations (such as civil society institutions, NGOs and Community based organizations).

2. The extension agencies should have a reorientation of their programs and activities, where women will be treated equally with their male counterparts. This will ensure more rural and agricultural development in the targeted area

3. Create an environment that encourages rural women's increased participation in extension, household decision-making and political areas.

4. Awareness raising programs about the importance of rural women's participation should be made both for males and females. Religious and rural leaders, women associations, civil societies, NGOs and mass media can play vital roles.

5. Raise awareness to enhance women's exercise of their political rights.
6. Develop and promote personal skills training courses for rural women on leadership, public-speaking, family planning, decisionmaking, and self-assertion;

7. Research needs to be conducted on the economic and social empowerment of rural women.

\section{REFERENCES}

Aref, F. and R. Ma'rof (2009). Community leaders' perceptions toward tourism impacts and level of building community capacity in tourism development. J. Sustainable Develop., 2 (3): 208-213.

Al-Leela, Z.H. and A.Z. Al-Hafidh (2011). Level of Rural Women Knowledge in Domain Food Industries and its relation with Some Variables In the villages of Shrikhan and Qubba/Nineva Governorate, Coll. Agric. and Forestry, Master Thesis.

Harbi, M.A.S. (1997). A Sociological Study of Women Participation in Egyptian Rural; Area, Coll. Agric, Al-Azher Univ.

Ismail, N.M.A. (2013). Knowledge level of rural women in the compound Baghirat, Dohuk Governorate in the Food industry and its relationship with some factors, Coll. Agric., Salahaddin Univ., Erbil, Diploma Thesis.

Sherif, D.M.M.S. (2005). Some social Factors Affecting the Degree of Rural Women Political Participation in Qualubia Governorate, Coll. Agric., Ain Shams Univ., Egypt.

World Bank (2008). Gender in agriculture, agriculture and rural development. 


\title{
مستوى المشاركة المحلية للمرأة الريفية في محافظة حلبجة بإقليم كردستان العراق
}

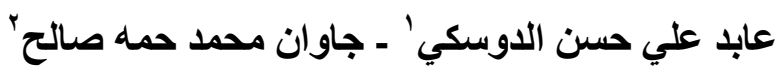

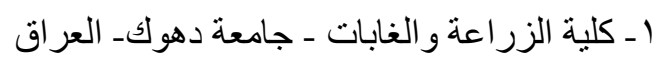

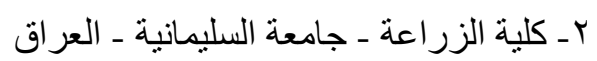

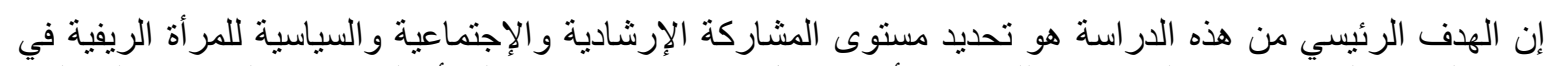

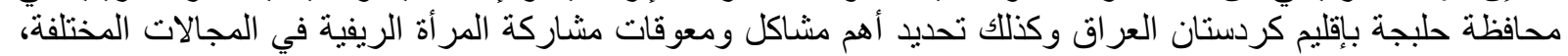

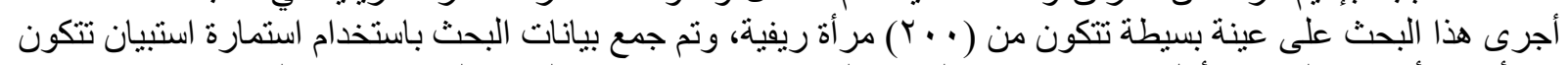

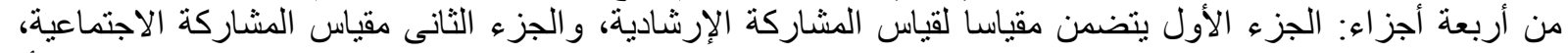

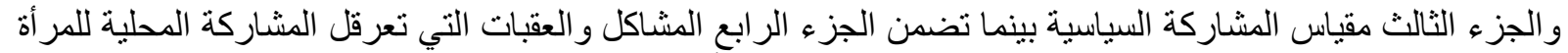

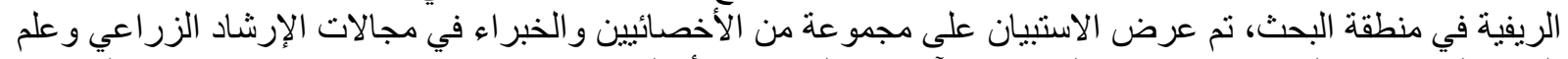

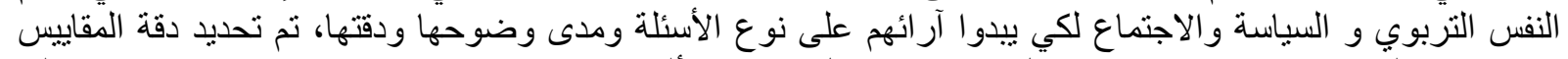

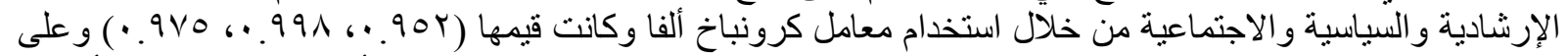

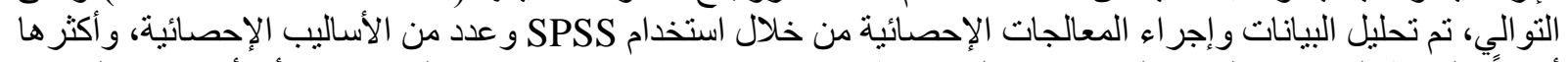

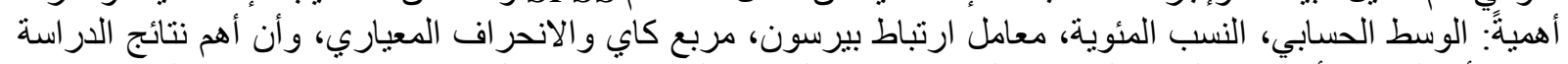

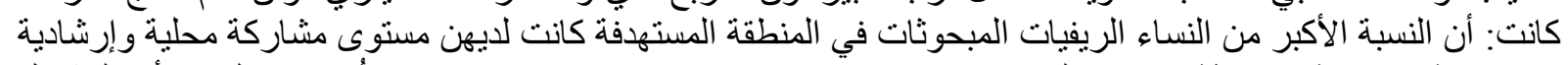

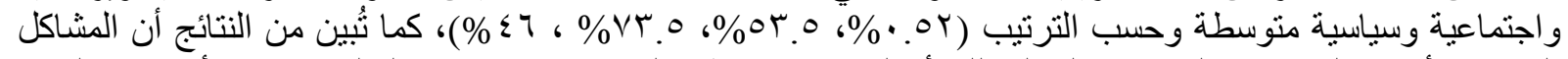

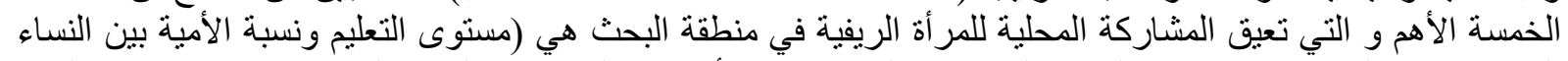

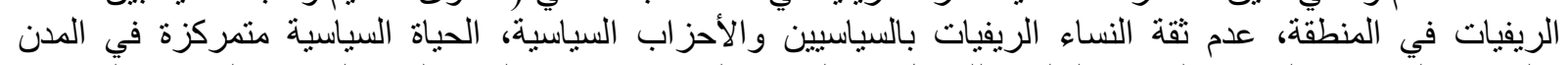

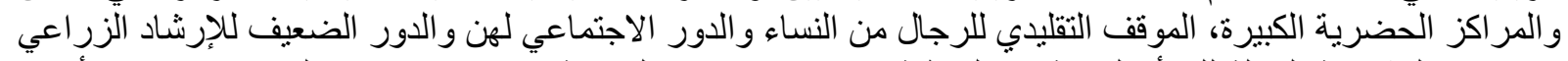

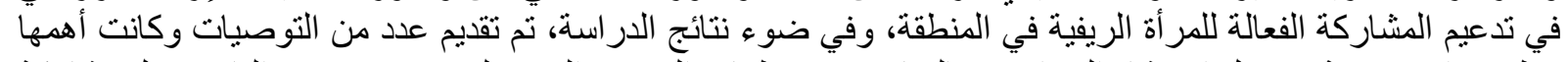

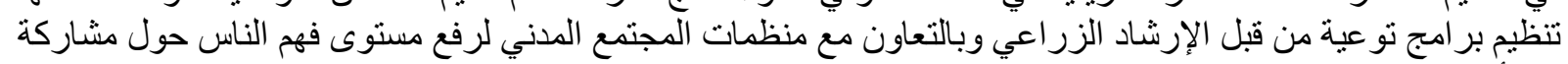
المر أة في برامج التنمية الريفية المستدامة.

أستاذ الإرشاد الزراعي ـ كلية الزر اعة - جامعة الزقازيق. أستاذ الإرشاد الزراعي الزراعي ـ كلية الزراعة الزراعة ـ جامعة الزقازيق. 